\title{
Urban food waste generation: challenges and opportunities
}

\author{
Bijaya K. Adhikari ${ }^{\mathrm{a}}$, Suzelle Barrington ${ }^{\mathrm{a}}$, José Martinez \\ ${ }^{\mathrm{a}}$ Department of Bioresource Engineering, Macdonald Campus of McGill University, \\ 21111 Lakeshore, Ste Anne de Bellevue (Québec) Canada, H9X 3V9 \\ Tel: 001-514-398-7776 ; fax : 001-514-398-8387; email : suzelle.barrington@mcgil.ca; \\ Bijayaadhikari@yahoo.com

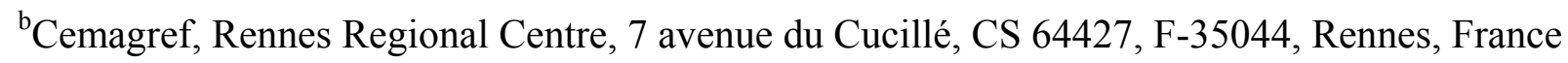 \\ Tel : 011332234821 21; Fax : 01133223482115 ; email : jose.martinez@cemagref.fr
}

\begin{abstract}
Greater economic activity and a wider economic gap between rural and urban areas have accelerated the growth of cities worldwide, along with their waste management issues. As a result, urban food waste (UFW) generation is expected to increase by 35\% from 2007 to 2025 . This paper examines the possible solutions to implement the environmentally safe recycling of UFW. If landfilling seems to be easy and economical for developed countries, it is not affordable for many large cities of Asia, Africa and South America. The on-site recycling of UFW is a more sustainable solution, but can only be justified economically if properly organized, community supported and recognized for its environmental benefits. On-site UFW composting is a solution which has already been implemented with success and which, if introduced worldwide, could provide agricultural soils with a good source of organic matter, capable of improving water management and fertilizing 3 million ha/yr. As compared to composting, anaerobic digestion could provide energy as biogas for a few high energy demanding industries within cities while also producing some organic soil amendment, after dewatering. Accordingly and for Asia and Africa, the on-site composting and anaerobic digestion of UFW could reduce the mass of MSW by 43 and
\end{abstract}


$55 \%$, respectively, thus help there cities manage almost all of their MSW. For North America and

Europe, such practice could reduce earth warming trends.

Keywords: urban; municipal solid waste; food waste; landfill; methane; compost; fertilizer; community

\section{Biographical notes:}

Bijaya K. Adhikari received his BSc in Agr. Engineering (Hons) in 1992, MSc in Hydraulic Engineering (2000) from International Institute for Infrastructural, Hydraulic, and Environmental Engineering (IHE), Delft, the Netherlands, MSc in Bioresource Engineering (2006) from McGill University, Montreal, Canada. He has several years work experience in the field of waste and water resources management. His areas of research include waste and water resources management. He is a member of Canadian Society of Bioengineering (CSBE), American Society of Agricultural and Biological Engineers (ASABE), Nepalese Society of Agricultural Engineers (NSAE) and Nepal Engineering Council (NEA). Currently, he is a Doctorate Student at the McGill University, Canada.

Suzelle F. Barrington received her B. Sc. (Agr. Eng.) and Ph. D. from McGill University, Canada, in 1973 and 1985. She is currently a full professor with the Department of Bioresource Engineering at McGill University and researches organic waste management and odour measurement and control. She is an active member of the Ordre des ingénieurs du Québec, is involved with Engineers Canada and is president of the Canadian Memorial Engineering Foundation supporting women in engineering with Canadian scholarships. She is a Fellow member of the Canadian Society of Bioengineering (CSBE) and a member of the American Society of Agricultural and Biological Engineers (ASABE). Along with Eco-quartier Jeanne Mance-Mile Ends, she received from the Canadian Geographic Society, the 2007 Canadian Environment Award for developing a fully functional and extremely active community composting centre in downtown Montreal. She has published over 400 articles of which 96 are refereed scientific publications.

Dr. José Martinez currently leads as research director, the Environmental Management and Biological Treatment of Wastes Research Unit at Cemagref, a public research body in France. He is also the former coordinator for the FAO research network Ramiran (Recycling of Agricultural Municipal and Industrial Residues in Agriculture Network), and adjunct Professor with the Department of Bioresource Engineering of McGill University. In 2004, he was invited by McGill University to deliver a semester course on "livestock farming and climate change". He has published over 50 scientific and technical papers on livestock slurries and manures. He has strong links with other member states through involvement in various competitively achieved EU projects including MATRESA, ALFAM, NUMALEC. Currently, his research interests are centered on $\mathrm{N}$ transformation processes in soils and manures, the reduction of greenhouse 
gases from organic waste management and utilization, and improving the efficiency of composting systems. 


\section{Introduction}

Besides population growth, two main factors will impact the earth's environment in the upcoming decades: economic growth especially for countries with a large population, like India and China; and greater economic disparity between rural and urban areas, driving the rural population into cities. While the first factor leads to a greater demand for resources, such as fossil fuels, metals, water and food, the second factor leads to a more costly waste management burden on large cities. Cities world wide are already experiencing waste handling problems and smog issues (Kumar et al., 2004).

From 20 to $80 \%$ of the mass of municipal solid waste (MSW) is made up of UFW. The UFW percentage was found to be inversely correlated to the economic status of the community, while the mass of UFW produced per capita was directly correlated (Adhikari et al., 2006). In many countries around the globe, the landfill practice is not even feasible, resulting in land and water dumping (Louis, 2004; Korfmacher, 1997). Because of its biodegradability, UFW attracts disease vectors such as parasites, pathogens, insects and vermin (Louis, 2004; Yedla and Parikh, 2001) and its proper disposal can improve the environment and reduce health risks. In Asia, for example, a large number of cities can generally afford the management of 10 to $30 \%$ of their MSW (Sharholy et al., 2007). Because the UFW fraction of such cities generally constitutes 50 to $70 \%$ of MSW, the on-site treatment of UFW could resolve most of the garbage issue, and in parallel, reduce the mass of MSW to be transported outside city limits, as well as the smog and greenhouse gas emissions.

Where landfilling is practiced, the UFW fraction has a major impact on water, soil

and air resources. Besides reducing the amount of land available for food production, landfilled UFW brings moisture producing contaminated leachate which can pollute 
groundwater and soils with heavy metals and toxic organic compounds (Louis, 2004; ElFadel et al., 2003). Landfilled UFW accelerates global warming by producing greenhouse gases $(\mathrm{GHG})$ composed of $60 \%$ methane $\left(\mathrm{CH}_{4}\right)$ and $40 \%$ carbon dioxide $\left(\mathrm{CO}_{2}\right)$ (Adhikari et al., 2006; Kumar et al., 2004; Bhide, 1994; Wang et al., 1997). Worldwide, the anthropogenic emission of greenhouse gases from landfill sites is estimated at $8 \%$ and results mainly from landfilled UFW. When installing systems to recover these greenhouse gases in young landfill sites, methane capture is costly and represent half of that produced from the anaerobic digestion of UFW (Ortega-Charleston et al., 2007).

Recycling UFW is a challenge even for developed countries. In the late 1990's and for Europe, only about $0.7 \%$ of the total organic fraction of MSW was treated anaerobically (Mata-Alvarez et al., 2000) and between 6 and 27\% was composted (De Baere, 2000) while the rest was sent to landfills along with the MSW main stream. In the early 2000's and for Canada, only the Maritime Provinces, with less than $10 \%$ of the country's population, were actively recycling over 50\% their UFW (Wagner and Arnold, 2006). The success of this recycling program relied on higher tipping fees for garbage, reaching \$100 US/ton, strict legislation and community training and involvement. Far from reaching this level in 2001, other Canadian provinces such as Quebec, with $20 \%$ of the country's population, were recycling only 7\% of their UFW (Da Costa et al., 2004).

Although source separation and the on-site treatment of UFW looks attractive from a health and environmental point of view, it is far from being implemented because the general public is not convinced of its economic feasibility (Isa et al., 2005; Kumar et al., 2004). The purpose of this paper is therefore to assess the challenges and economic benefits of the on-site recycling of UFW within an urban context, and to evaluate the 
opportunities resulting from the conversion of UFW into useful resources. The following sections will investigate the cost of UFW handling and landfilling versus the benefits of recycling the organic matter either as a fertilizer, through composting, or an energy source through anaerobic digestion.

\section{Continental MSW and UFW generation}

The estimated continental growth in MSW and UFW is presented in Figures 1a and 1b (Adhikari et al., 2006), assuming no changes in the present economic trend. With the largest share of world population, Asia produces the largest amount of MSW which is expected to increase from $617 \mathrm{Gkg} / \mathrm{yr}$ in 2007 to $967 \mathrm{Gkg} / \mathrm{yr}$ in 2025; during this time, UFW production will grow from $278 \mathrm{Gkg} / \mathrm{yr}$ to $416 \mathrm{Gkg} / \mathrm{yr}$. Asia is followed by the Americas with $130 \mathrm{Gkg} / \mathrm{yr}$ of UFW in 2007, which is expected to increase to $174 \mathrm{Gkg} / \mathrm{yr}$ in 2025. Europe and Africa are producing 98 and $53 \mathrm{Gkg} / \mathrm{yr}$ of UFW in 2007, and this production is expected to reach $113 \mathrm{Gkg}$ and $87 \mathrm{Gkg} / \mathrm{yr}$ in 2025 .

\section{INSERT FIGURES 1A AND B}

The estimations presented in Figures $1 \mathrm{a}$ and $1 \mathrm{~b}$ consider the impact of the wider economic gap between rural and urban populations. In Asia, this gap is widening and attracting rural communities to move towards cities with the expectation of a better life. Adhikari et al. (2006) demonstrated a clear relationship between the economic development of a country and the displacement of its population from rural areas to urban centres. By maintaining their present economic growth, most Asian countries such as China and India, could see their urban population growing from the present $50 \%$ to a 
future $70 \%$, such as found in Europe and North America (Table 1). The recycling of UFW is not an issue for rural populations because of the space and land at their disposal.

\section{INSERT TABLE 1}

In comparison to Adhikari et al. (2006), Sharholy et al. (2007) estimated that $90 \%$ of the MSW produced in India's urban centres is improperly disposed of, leading to serious environmental and health risks for the population. Sharholy et al. (2007) also reported that the general urban population was producing some $0.4 \mathrm{~kg} / \mathrm{capita} /$ day of MSW in 1999 and that its UFW content ranged from 45 to $60 \%$, for a net UFW production of $0.2 \mathrm{~kg} / \mathrm{capita} /$ day. Adhikari et al. (2006) estimated that in 2007 , due to economic growth, the urban population of India could be producing $0.34 \mathrm{~kg} / \mathrm{capita} / \mathrm{day}$ of UFW (Table 1).

In the following sections, estimates of resource requirements will be presented for countries around the world to properly dispose of all their UFW through landfilling. Then, the savings in resources will be estimated if on-site composting and anaerobic digestion were used instead of landfilling.

\section{Disposal of UFW through landfilling}

Landfilling is presently the most widely accepted practice for the disposal of MSW (De Baere, 2000). Although this solution is attractive to large cities, it lacks in scope and overall resource sustainability besides creating a poor environment for those living close to the landfill site. Environmental issues introduced by landfill sites are: risk of groundwater contamination from the leachate, greenhouse gas emissions, truck circulation bringing noise, dust and smog, and garbage decomposition creating odours. 
Furthermore, landfills require more often than not, the sacrifice of good agricultural soils which otherwise could be used to feed the world.

\subsection{Land used for UFW landfilling}

In terms of agricultural land, landfills occupy large areas which can no longer be used for food production, because of contamination risks. Typically and with a density of 260 to $500 \mathrm{~kg} / \mathrm{m}^{3}$, each Gkg of urban UFW requires 33 ha of land when piled to a height of $15 \mathrm{~m}$ using a waste to soil cover ratio of 5:1 (Peavy et al., 1985; Bhide, 1994). When extrapolating this number and assuming that all future UFW generation will be landfilled, MSW management is observed to have an impact on world agricultural land and food production capacity.

In Asia and for 2007, the annual land use is estimated at 9174 ha for UFW landfilling and this area is expected to increase to 13728 ha in 2025 . Similarly, the Americas will require $5742 \mathrm{ha} / \mathrm{yr}$ in 2025 , which is a $40 \%$ increase compared to that required in 2007. Europe and Africa (Figure 2) follow in terms of land use for landfilling, with an estimated increase of 18 and $70 \%$ in 2025 as compared to 2007, respectively.

\section{INSERT FIGURE 2}

Over the upcoming 18 years (2007-2025), the landfilling of all UFW could require some $400 \times 10^{3}$ ha of land with a deep soil profile. In Asia alone, the land area required for such purpose is estimated at $210 \times 10^{3}$ ha, representing $53 \%$ of total global land requirement for landfilling. If UFW was recycled, an equivalent amount of land could be maintained in agricultural production to produce food for the Asian population. 
A surface area of $210 \times 10^{3}$ ha can grow enough wheat, at 2.0 metric ton/ha, to provide a population of 1.0 million with $100 \%$ of its carbohydrate requirements.

Many large cities around the globe are suffering from lack of landfilling space for the disposal of their MSW. The city of Singapore plans to build an off-shore island of 350 ha to dispose of its MSW for the upcoming 30 years; the creation of this land base alone will cost almost $\$ 10 \mathrm{US} /$ ton of MSW, while the land base for a landfill site in Ohio State cost $\$ 0.10$ US/ton (Ohio State University, 2001). Where the land and handling costs cannot be afforded, open spaces, street corners and river banks serve as uncontrolled dumping sites for as much as $90 \%$ of all MSW (Sharholy et al., 2007).

In developed countries, landfill sites use good agricultural land which is becoming a national priority, and bring other forms of regional pollution besides. Landfill sites are often forced onto rural communities to allow urban centres to dispose of their MSW, and as such, introduce additional contamination in the form of truck traffic, dust and odours. Recently, North American authorities introduced laws for the cleaning and restoration of old landfill sites (Minnesota Pollution Control Agency, 2004). Urban sprawl is becoming a threat to agricultural land, as many government authorities are initiating laws to preserve farm land; agricultural land protection legislation has been implemented in Canada, the United States, Australia and Europe (USDA, 2005). In the United States from 1992 to 2001, urban regions have tripled in area, at a growth rate of $100 \times 10^{3} \mathrm{ha} / \mathrm{yr}$. During this same period, landfilling operations have reduced US land surfaces designated for agriculture at an additional rate of $1.5 \times 10^{3} \mathrm{ha} / \mathrm{yr}$. Finally, agricultural land will be even more pressing in the years to come, as the transformation of corn into ethanol is expected to compete with fossil fuel production. From 2005 to 2025, in the Americas 
alone, landfill sites will remove $110 \times 10^{3}$ ha of land, which could produce enough ethanol to replace a net (energy above that required to produce the ethanol) amount of $147 \times 10^{3} \mathrm{~m}^{3}$ of diesel/yr (USDA, 1995). Although this diesel represents only a small percentage of the world demand of 4 million $\mathrm{m}^{3}$ of diesel/day for 2007 (US EIA, 2007), it represents $1.3 \%$ of Canada's 2007 consumption. In terms of meeting the Kyoto agreement, this is a major share of Canada's $6 \%$ reduction commitment.

\subsection{Cost of handling and landfilling urban UFW}

The land base required for landfill sites often represents the tip of the iceberg (Isa et al., 2005). In North America, the purchasing of land represents only $0.5 \%$ to $1.0 \%$ of the total cost of handling and disposing of MSW. Besides the land base, environmentally safe landfills require the expertise of professionals, the construction of access roads, the installation of impermeable membranes and the collection and treatment of leachate. In 2001, the implementation, operation (transportation of MSW to the site and burial) and closure of a safe landfill site for $5.4 \mathrm{Gkg}$ of solid waste were estimated at $\$ 20 \mathrm{US} / \mathrm{ton}$, in Ohio State, USA (Ohio State University, 2001). Since the collection cost is in the range of $\$ 16.00 \mathrm{US} /$ ton (Smart Storage, 1998), the total MSW management cost amounts to \$36 US/ton. The operations of collecting, transporting and landfilling consume fossil fuels at a rate of 10L/ton (Ohio State University, 2001; University of Tennessee, 1993). Although the handling of all UFW, world wide, would only use $0.4 \%$ of the world's diesel consumption, it is still equivalent to $50 \%$ of Canada's requirements. Nevertheless, the energy cost generally represents $10 \%$ to the total cost of handling and disposing of 
MSW, while the labour cost represents $70 \%$ and the capitalization and maintenance costs add up to $20 \%$.

Mumbai spends some \$29 US/ton for the collection, transportation and landfilling of what ever MSW can be handled (Department of Chemical Engg, 1997). Similarly and in 2000, the Malaysian MSW handling cost of $\$ 16$ US/ton, along with its waste generation of $0.8 \mathrm{~kg} /$ capita/d (Tean, 2001), implies that $\$ 105$ million US/year would be required to the waste generated by a population of 23 million (Isa et al., 2005). The low labour cost, despite higher land cost, makes landfilling a cheaper operation in Asia than in North America.

If the present landfill practice is maintained and the entire wet mass of UFW is landfilled, the cities around the world are facing huge economic challenges (Figure 3). At present, Asia needs $\$ 10$ billion US/yr for the handling of its urban UFW and is expected to spend $\$ 15$ billion US/yr more in 2025 . The Americas are next, presently spending $\$ 4.5$ billion US/yr and expected to increase this spending by $\$ 6.2$ billion US/yr, in 2025 . Whereas in Europe, $\$ 3.4$ billion US/yr is estimated for 2007, the cost is expected to increased by $18 \%$ in 2025; Africa needs $\$ 1.8$ billion US $\$$ yr in 2007 and its cost is estimated to increase by $71 \%$, in 2025 .

\section{INSERT FIGURE 3}

Landfilling brings no economic benefit, besides providing employment. The recovery of methane is costly and only $50 \%$ efficient (Ortega-Charleston et al. 2007) as compared to directly digesting UFW using an anaerobic digester. Some $200 \mathrm{~L}$ of methane/ton of landfilled UFW (dry basis) (Wang et al., 1997) need collecting and flaring at a cost of $\$ 4.00 \mathrm{US} /$ ton of wet UFW (Ngnikam et al., 2002). The transformation 
of this methane into electricity is even more expensive, because of its low conversion efficiency of $35 \%$.

\subsection{Total cost of landfilling urban UFW}

In total, the collection, transportation, landfilling of UFW and the greenhouse gas ramification is a non sustainable operation which costs in the range of $\$ 20$ to $\$ 40 \mathrm{US} /$ ton UFW, depending on labour and land costs. For developing countries, this cost is often not affordable despite the health issues at stake. For developed countries, this cost is too affordable, and the resources required are relatively limited, explaining the lack of UFW recycling. The on-site recycling of UFW will be implemented for both developing and developed countries, when additional benefits are considered, from an aspect of environment and resource conservation.

\section{On-site treatment and utilization of urban UFW}

Considering the environmental issues associated with the landfilling of the world's UFW, alternative sustainable solutions must be developed. The implementation of these solutions requires the involvement of communities, through awareness programs and incentives, and the logical valorization of the organic waste.

\subsection{Source separation}

Source separation is a pre-requisite for the on-site treatment of UFW to reduce MSW handling, transportation and landfilling costs, especially for large cities. In 2025, such 
practices could reduced by $43 \%$ the total MSW disposal cost in Asia, 29\% in Americas, $29 \%$ in Europe and 53\% in Africa (Figure 4).

\section{INSERT FIGURE 4}

In the past, many countries around the world have developed large scale composting centers for organic waste which was mechanically separated from MSW. Many of these composting centres have not been kept in operation (Sharholy et al. 2007) for three reasons: the poor quality of the compost resulting from its contamination with glass, heavy metals and other pollutants into contact with the acidic leachate during handling; the workers often get hurt while handling and sorting the various components of the MSW; and the value of the compost produced being lower than the cost of composting (Furedy et al., 2007).

\subsection{Composting source separated UFW - a success story}

The authors of the present paper were involved with the implementation of a successful on-site composting centre operating in the heart of the city of Montreal, Canada (Barrington et al., 2005). In operation since 2003, the composting centre is located in a municipal park, along a popular pedestrian path. The 125 participating families are source selecting and dropping of their UFW on their way to work in the morning, three times weekly, when an attendant operated the centre. The composting centre is visible to all walking by, and those curious enough can stop to ask questions.

The successful operation of this $6.0 \mathrm{~m}^{3}$ centre was based on three main elements: the implementation of community awareness, training and educational programs before opening the centre; the easily accessible and visible site selected for the urban 
composting centre; and the fact that most of the local residents were highly educated, with at least a university degree.

In 2007 and with a capacity of 1.0 tons of high quality compost/week, this Montreal centre operates at a cost of $\$ 220 \mathrm{US} /$ ton of finished material or $\$ 140 \mathrm{US} /$ ton of wet UFW processes. Labour, power, bulking agent and capitalization represent 40, 1, 9 and $50 \%$ of the costs. As bulking agent, the centre uses pellets of cereal flour residues, because of their high moisture absorbing capacity. The operating cost of this centre could be reduced to $\$ 70$ US/ton of UFW ( $\$ 110$ US/ton of compost produced) if the capacity was increased to 5 tons/week of compost. Although similar in cost to that of larger operations, composting obviously does not seem economical when compared to landfilling and its methane recovery at $\$ 40$ US/ton UFW (US EPA, 2003; US EPA, 1999).

\subsubsection{Proposed on-site UFW composting for Mumbai, India}

Flooding is a threat to public health in Indian cities because of the uncontrolled street dumping of MSW. Composting could therefore be a highly suitable solution, along with the fact that once recycled as soil amendment, water conservation and soil fertilization practices can be enhanced (Kumar et al., 2004).

Mumbai is one of the biggest cities in India with a population 27000 per $\mathrm{km}^{2}$ (Demographia, 2007). Its MSW management is one of the major challenges because of a waste production rate exceeding $0.50 \mathrm{~kg} /$ person/day (Department of Chemical Engg, 1997) with over 50\% UFW (Adhikari et al., 2006). 
Table 2 presents a scenario where the Montreal park composting centre could be implemented in Mumbai. To deal with the intense population, it is proposed to use 6 invessel composters per $\mathrm{km}^{2}$, each with a capacity of $27 \mathrm{~m}^{3}$. The operating cost for such centre could be lower than that of Montreal, because of cheaper labour costs and the larger capacity of the system. The compost production cost is estimated at $\$ 85 \mathrm{US} / \mathrm{ton}$, implying a cost of eliminating UFW of $\$ 53.00$ US/ton on a wet basis. Nevertheless, these composting centres would first of all require the participation of the population to source separate UFW and bring it to the composting centres. Because not all the population is environmentally aware and committed to environmental issues, monetary incentives may be required.

\section{INSERT TABLE 2}

As for Montreal, this composting cost of $\$ 85.00 \mathrm{US} /$ ton for Mumbai is still above that of $\$ 39.00$ US for landfilling. Hence, promoting the on-site recycling of UFW requires the demonstration of additional benefits, for both developed and developing countries.

\subsubsection{Advantages of on-site UFW composting}

Once composted, UFW are stabilized, of lower moisture content and have lost $50 \%$ of their original mass (US EPA, 2003). At present, Asia has a compost production potential of $83 \mathrm{Gkg}$ and its production is expected to increase by $51 \%$ in 2025 (Table 3). In the Americas, compost production from UFW can potentially amount to $52 \mathrm{Gkg}$ in 2025 , which is $37 \%$ higher than that of 2007 . In Europe and Africa, the compost production 
potential is estimated at 34 and $26 \mathrm{Gkg}$, which represents an increase of 18 and $73 \%$ compared to 2007.

\section{INSERT TABLE 3}

To compare the cost of composting UFW with that of landfilling, all benefits must be considered (Table 4). First of all, this compost has a mineral fertilizer value because each dry ton of compost produced from UFW can potentially offer $24 \mathrm{~kg} \mathrm{~N}, 2.4 \mathrm{~kg} \mathrm{P}$ and $32 \mathrm{~kg} \mathrm{~K}$ (Adhikari et al., 2006). In Asia, the value of N, P and $\mathrm{K}$ is $\$ 0.25, \$ 0.65$ and $\$ 0.65$ US $/ \mathrm{kg}$, while in North America the value is $\$ 1.15, \$ 1.15$ and $\$ 0.60 \mathrm{US} / \mathrm{kg}$ (Barrington, 2007). The cost recovery from the fertilizer value of compost produced from the entire Asian urban UFW is estimated at $\$ 1418$ million US/yr in 2007 and is expected to increase by $50 \%$ in 2025 , while in the Americas it will reach $\$ 1550$ million US/yr in 2025. In Europe and Africa, the 2025 value is estimated at $\$ 995$ and $\$ 435$ million US/yr. If all UFW was properly separated and composted in Asia, some 3 million ha could be fertilized with $40 \mathrm{~kg}$ of $\mathrm{P} / \mathrm{ha}$ (the equivalence of $28 \mathrm{~kg}$ of $\mathrm{P} / \mathrm{ha}$ in mineral fertilizer), which in turn, could feed 12 million persons. Illegally disposed of along river banks or leached to groundwater as landfill leachate, this phosphorous has a tremendous eutrophication impact.

\section{INSERT TABLE 4}

The application of UFW compost, at a rate of $40 \mathrm{~kg}$ of $\mathrm{P} / \mathrm{ha} / \mathrm{yr}$, adds $33 \mathrm{tons} / \mathrm{ha} / \mathrm{yr}$ of organic matter or $1.4 \% / \mathrm{yr}$, over a depth of $200 \mathrm{~mm}$. Such rate of organic matter application to land can help reduce erosion and improve fertilizer and water absorption, thus advantage the quality of water resources. The value of organic matter in reducing 
risks of erosion and mineral fertilizer leaching needs further investigation, but in this paper will be evaluated as equal to its mineral content. Similarly, $1.0 \mathrm{~kg}$ of dry compost can absorb up to $3.0 \mathrm{~kg}$ of water and $2.0 \mathrm{~kg}$ of this water is readily available to plants (Soussi et al., 2006). The land application of compost, at a rate of 33 tons $/ \mathrm{ha} / \mathrm{yr}$, can therefore improve water retention by $7 \mathrm{~mm}$ following rainfall events, and thus reduce irrigation requirements. This is particularly interesting because water is becoming an increasingly precious commodity. Table 4 estimates the water holding value of UFW compost using a cost for wholesale water of $\$ 0.50 \mathrm{US} / \mathrm{m}^{3}$, which corresponds to water obtained from reservoirs. When the water is obtained by desalination, the cost ranges between $\$ 0.75$ to $\$ 1.00 \mathrm{US} / \mathrm{m}^{3}$ (Hamer, 2007).

Finally, the on-site composting of UFW eliminates a major portion of the MSW handling, landfilling and greenhouse gas recovery costs. On-site composting in urban areas allows local residents to bring their UFW to the composting centre as opposed to hiring expensive equipment for the collection. Furthermore, composting reduces the mass of FW by $50 \%$, even after adding a bulking agent, and this compost can be used on farm land on the outskirts of the city whereas landfills are further away to avoid nuisance. Accordingly, collection and transportation of UFW can be reduced by over $50 \%$ and landfill greenhouse gas emissions are dropped to negligible levels, eliminating the need for their recovery.

When considering all benefits introduced with the on-site composting of UFW, composting becomes a profitable operation. Considering all the added benefits as soil amendment, farm land users will most likely be willing to use the compost in Asia as well as in North America. The high quality of the compost will be an added value. 


\subsection{On-site anaerobic treatment of UFW and energy generation}

Besides composting, anaerobic digestion is the other available technology to treat UFW on-site. Anaerobic digestion produces biogas which can replace natural gas, does not require the purchase of bulking agents and can deodorize UFW rather than release odours. Nevertheless, composting produces a dry, stabilized and volume reduced product, as opposed to anaerobic digestion which generates a large volume of wet and nondisinfected sludge (Bagge et al., 2002) requiring dewatering to produce a high quality soil amendment.

At present, the anaerobic treatment of the Asian UFW can produce $17 \mathrm{Gkg}$ of $\mathrm{CH}_{4}$ and this production is estimated to increase to $25 \mathrm{Gkg}$, in 2025 (Table 5a). If burned to get the highest conversion efficiency of $56 \mathrm{MJ} / \mathrm{kg} \mathrm{CH}_{4}$ (EDM, 2007), the 2025 energy recovery potential from UFW in Asia is equivalent to $1400 \times 10^{12} \mathrm{KJ} / \mathrm{yr}$ which also represent 44 million $\mathrm{kW}$ of energy generation on a continuous basis (Table 5b). Similarly, the urban UFW from the Americas, Europe and Africa can produce $616 \times 10^{12}$ $\mathrm{KJ}, 392 \times 10^{12} \mathrm{KJ}$ and $280 \times 10^{12} \mathrm{KJ}$ of energy respectively, in 2025. If all urban UFW could be anaerobically treated on-site, the total global energy recovery for 2025 is estimated at $2688 \times 10^{12} \mathrm{KJ}$; Asia alone could produce $52 \%$ of total energy recovery. Nevertheless, this only represents $1.4 \%$ of the energy offered by the 15 million $\mathrm{m}^{3} / \mathrm{d}$ of crude oil presently utilized by the world.

\section{INSERT TABLES 5a and $b$}

When compared to the total world energy demand including that obtained from crude oil, the conversion of UFW into biogas represents less than $0.5 \%$ (Table 6). Even 
for India, UFW could only generate $0.66 \%$ of all of its energy needs. For the anaerobic digestion of UFW to produce at least $1 \%$ of the world energy, in terms of biogas, wastewater sludge and green wastes (ex. grass clippings) will have to be added.

\section{INSERT TABLE 6}

Justifying biogas production from UFW therefore requires its use by a plant with a high demand for clean fuels, such as a food processing plant, a foundry or a community heating plant. The anaerobic digestion of the UFW and sludge produced by a population of 1.0 million represents $10 \mathrm{GW}$ of power (100\% efficiency), which becomes interesting when used by a single large plant. Sludge added to the UFW can provide sufficient liquid to liquefy the UFW for its anaerobic digestion, but introduces additional health risks for the workers.

\subsubsection{Community UFW anaerobic treatment centres for Mumbai, India}

Energy is one of the major issues for the city of Mumbai, India. Each anaerobic digester implemented per $\mathrm{km}^{2}$ of urban area could generate $130 \mathrm{~kW}$ of power on a continuous basis, assuming $100 \%$ efficiency (Table 7). This energy could easily be used by a factory or industry, but could not be distributed to all the contributing families. As opposed to 6 composting centres $/ \mathrm{km}^{2}$, one anaerobic digester $/ \mathrm{km}^{2}$ is preferred to optimize the size of the operation. Thus, local communities would need more incentives to bring their UFW for treatment. The sludge produced would need pasteurization and dewatering before being suitable for soil fertilization (Hartmann et al., 2004). Sludge produced by the anaerobic digesters could be used as soil amendment by nearby gardens rather than farm land outside the city limits, to eliminate the need for dewatering. 


\section{INSERT TABLE 7}

The benefits of anaerobically digesting UFW can be analyzed, as done for composting (Table 8). The anaerobic digestion of UFW generates less organic matter but just as much mineral fertilizer as composting. In exchange, biogas produces energy and eliminates most cost associated with landfilling, except for the collection and $75 \%$ of the transportation. As for composting, anaerobic digestion becomes interesting when considering the added benefits on the environment and world resources.

\section{INSERT TABLE 8}

\section{Conclusions}

The rapid urbanization and growing economic activity around the world accelerates the generation of municipal solid waste (MSW) and urban food waste (UFW) within city limits, especially in developing economy. While presently most large city in Asia, Africa and South America does not have the funds to even collect all of its MSW, those in North America and Europe do not see the incentives to recycle UFW.

The on-site recycling of UFW through composting or anaerobic digestion can be demonstrated as attractive when considering all benefits, including those having an effect on the environment and the world water, soil and air resources. Source separation is a pre-requisite to successfully compost and to anaerobically digest UFW, with the least risk of contamination for agricultural soils and the food supply chain. The organic matter recycled by such treatment technologies could produce a soil amendment capable of fertilizing 3 million ha/yr while increasing the soil organic matter by $1.4 \% / \mathrm{yr}$ and the water retention by $7 \mathrm{~mm}$. If composting requires a plentiful source of bulking agents and a 
biofilter for odour control, anaerobic digestion requires additional hygienic protection for the operators and sludge users.

\section{Acknowledgement}

The authors gratefully acknowledge the continued financial supported by the Natural

Science and Engineering Research Council of Canada and cemagref, France.

\section{References}

Adhikari, B.K., Barrington, S., Martinez, J. (2006) 'Predicted growth of world food waste and methane production' Waste Management \& Research, Vol. 24, pp. 421-433.

Australia EPA (2003) 'Alternatives to landfills - cost structure and related issues' Australia Environmental Protection Agency, Government of South Australia, Adelaide. pp108.

Bagge, E., Shlstrom, L. Albihn, A. (2002) 'Hygienic aspects of recycling of organic waste in biogas plants' Proceedings of Agricultural, Municipal and Industrial Residues in Agriculture. Ramiran 2002. FAO European Cooperative Research Network.

Barrington, S. (2007) Personnel contact in Canada and at Tamil Nadu University of Coimbatore, India. McGill University, Montreal, Canada.

Barrington, S., Adhikari, B., Gregoire, B. (2005) 'An urban composter to induce the culture of residential organic waste sorting' Proceedings form Waste - The social Context, University of Alberta. Edmonton, Alberta.

Bhide, A.D. (1994) 'Methane emission from landfills' Journal of Indian Association for Environmental Management, Vol. 21, pp. 1-7.

De Baere, L. (2000) 'Anaerobic digestion of solid waste: state - of - the- art' Water Science \& Technology, Vol. 41, pp. 283-290.

Da Costa, E., Gewerts M., Hanley, K., Kulhanek, S., McKelar, K. (2004) 'Creating a composting infrastructure for the city of Montreal. Sierra Club of Canada, Quebec Group. McGill University School of the Environment, McGill University, Montreal, Canada.

Demographia (2007) 'Demographia world urban areas, projections 2007 \& 2020 (world 
agglomerations)' www.demographia.com/db-worldua2015.pdf (Accessed on: 17 April 2007).

Department of Chemical Engg (1997). In: Kumar, S., Gawaikar, V., Gaikwad, S. A. and Mukherjee, S. (2004) 'Cost-benefit analysis of landfill system with gas recovery for municipal solid waste management: A case study' Intern. J. Environ. Studies, Vol. 61, No. 6, pp. 637-650.

EDM, (2007) 'Energy density of methane' http://hypertextbook.com/facts/2004/BillyWan.shtml (Accessed on: 20 April 2007).

El-Fadel, M., Bou-Zeid, E., Chahine, W. (2003) 'Landfill evolution and treatability assessment of high-strength leachability from MSW with high organic and moisture content' Intern. J. Environ. Studies, Vol. 60, No. 6, pp. 603-615.

Furedy, C., Maclaren, V., Whitney, J. (2007) 'Recycling organic wastes for food production in asian cities: sanitary and economic perspectives' International Development Research Council of Canada, on-line publications. www.idrc.ca/fr/ev-30609-201-1-DO_TOPIC.html

Hamer, W.G. (2007) 'The cost of water and water markets in South California, USA' In: Water Resource Management IV. WIT Press, Southampton, Boston, USA. pp489498.

Hartmann, H., Mфller, H.B., Ahring, B.K. (2004) ' Efficiency of the anaerobic treatment of the organic fraction of municipal solid waste: collection and pretreatment' Waste Manage Res., Vol. 22, pp. 35-41.

Isa, M.H., Asaari, F.A.H., Ramli, N.A., Ahmad, S., Siew, T.S. (2005) ' Solid waste collection and recycling in Nibong Tebal, Penang, Malaysia: a case study' Waste Manage Res., Vol. 23, pp. 565-570.

Korfmacher, K.S. (1997) ' Solid waste collection systems in developing urban areas of South Africa: an overview and case study’ Waste Manage Res., Vol. 15, pp. $477-$ 494.

Kumar, S., Gawaikar, V., Gaikwad, S. A., Mukherjee, S. (2004) 'Cost-benefit analysis of landfill system witrh gas recovery for municipal solid waste management: A case study' Intern. J. Environ. Studies, Vol. 61, No. 6, pp. 637650 .

Louis, G.E. (2004) ' A historical context of municipal solid waste management in United States' Waste Manage Res., Vol. 22, pp. 306-322.

Mata-Alvarez, J., Mace, S., Llabres, P. (2000) ‘ Anaerobic digestion of organic solid 
Wastes' An overview of research achievements and perspectives' Bioresource Technology, Vol. 74, pp. 3-16.

Minnesota Environmental Protection Agency (2004) 'Minnesota closed landfill program - 2004 Annual Report to the Legislature' St Paul, Minnesota.

Ngnikam, E., Tawana, E., Rousseaux P., Riedacker, R. (2002) 'Evaluationof potentialities to reduce GHG emissions resulting from various treatments of municipal solid wastes in moist tropical climates: application To Yaounde' Waste Management \& Research, 20 (6), pp. 501-513.

Ohio State University (2001) 'Landfill cost model for disposal of coal combustion products' Fact sheet. Department of Civil and Environmental Engineering and Geodetic Science \& OSU Extension, Columbus, Ohio, USA.

Ortega-Charleston, L., Barrington, S. F., Guiot, S. R. (2007) 'Thermophilic adaptation of a mesophilic anaerobic sludge for food waste treatment' Journal of Environmental Management. In press

Peavy, H.S., Rowe, D.R., Tchobanoglous, G. (1985) ' Environmental Engineering' McGraw-Hill, Inc. USA. pp 640-644.

Sharholy, M., Ahmad, K., Mahmood, G., Triveli, R.C. (2007) 'Municipal solid waste management in Indian cities - A review' Waste Management. In press.

Smart Storage (1998) 'Landfill problems, US landfill facts' http://wwwesd.lbl.gov/ECO/smart_store/problems.html. (Accessed on: 14March 2007).

Soussi, A., Masse, L., Barrington, S. (2006) 'Biofiltration and greenhouses gas reduction in manure pit and livestock facilities' NABEC technical conference, Montréal, Canada. Paper 06-P015. ASABE, St Joseph, Michigan, USA.

Tean, S.N. (2001). In: Isa, M.H., Asaari, F.A.H., Ramli, N.A., Ahmad, S. and Siew, T.S. (2005) 'Solid waste collection and recycling in Nibong Tebal, Penang, Malaysia: a case study' Waste Manage Res., Vol. 23, pp. 565-570.

University of Tennessee (1993) 'Solid waste transportation and other costs' County Technical Assistance Service, Knoxville, Tennessee.

USDA (1995) 'Estimating the net energy balance of corn ethanol' Agricultural Economic Report 721. United State Department of Agriculture, Economic Research Service, Washington DC, USA

USDA (2005) 'Land use, value and management - Urbanization and agricultural land' United State Department of Agriculture, Economic Research Service, Washington DC, USA 
US EIA (2006) 'International energy outlook' U. S. Energy Information Administration, Washington, D.C., U.S.A.

US EPA (1999) 'Organic waste management strategies' United States Environment Protection Agency, Washington, DC, USA.

US EPA (2003) 'Alternatives to landfills - Cost structures and related issues' United States Environment Protection Agency, Washington, DC, USA.

Yedla, S., Parikh, J. K. (2001) 'Economic evaluation of a landfill system with gas recovery for municipal solid waste management: a case study' International Journal of Environment and Pollution, Vol. 15, No. 4, pp. 433-447.

Wagner, T., Arnold, P. (2006) 'A new model for solid waste management: an analysis of the Nova Scotia MSW strategy' Journal of Cleaner Production. In press

Wang, Y., Odle, W.S., Eleazer, W.E., Barlaz, P. (1997) 'Methane potential of food waste and anaerobic toxicity of leachate produced during food waste decomposition' Waste Management \& Research, 15, pp. 149-167.

West, M.E., Brown, K.W., Thomas, J.C. (1998) 'Methane production of raw and composted solid waste in simulated landfill cells' Waste Management \& Research, 16 (5), pp. 430-436. 


\section{List of tables:}

Table 1 Total and urban population for various countries and their food waste generation Table 2 Community composting centers for Mumbai, India

Table 3 Estimated annual continental compost production from urban food waste (UFW) in $\mathrm{Gkg}$

Table 4 Value of composted UFW for Asia and North America

Table 5a Continental methane $\left(\mathrm{CH}_{4}\right)$ production from the anaerobic digestion of UFW in $\mathrm{Gkg} / \mathrm{yr}$

Table $5 \mathrm{~b}$ Continental energy recovery potential from the anaerobic digestion of UFW in $10^{12} \mathrm{KJ} / \mathrm{yr}$

Table 6 Total energy need versus that recovered from UFW anaerobic digestion

Table 7 Example of urban anaerobic UFW digester for Mumbai, India

Table 8 Value of anaerobically digested UFW for Asia and North America 
Table 1 Total and urban population for various countries and their food waste generation

\begin{tabular}{|c|c|c|c|c|c|}
\hline \multirow[t]{2}{*}{ Continent } & \multirow[t]{2}{*}{ Country } & \multicolumn{2}{|c|}{ Population } & \multicolumn{2}{|c|}{$\begin{array}{l}\text { Food waste } \\
\text { generation }\end{array}$} \\
\hline & & $\begin{array}{c}\text { Total } \\
10^{6}\end{array}$ & $\begin{array}{c}\text { Urban } \\
\%\end{array}$ & $\begin{array}{l}\text { UFW } \\
\mathrm{kg} / \mathrm{c} / \mathrm{d}\end{array}$ & $\begin{array}{l}\text { UFW } \\
\text { Gkg/d }\end{array}$ \\
\hline \multirow[t]{5}{*}{ Africa } & Algeria & 30.24 & 59.3 & 0.34 & 6.1 \\
\hline & Ethiopia & 65.59 & 17.7 & 0.33 & 3.8 \\
\hline & Kenya & 30.55 & 33.1 & 0.37 & 3.7 \\
\hline & Morocco & 29.11 & 55.3 & 0.35 & 5.6 \\
\hline & Niger & 10.74 & 20.6 & 0.50 & 1.1 \\
\hline \multirow[t]{4}{*}{ Asia } & China & 1275.2 & 52.0 & 0.34 & 243.0 \\
\hline & India & 1071.0 & 42.0 & 0.34 & 153.0 \\
\hline & Kuwait & 2.25 & 97.6 & 0.60 & 1.32 \\
\hline & S. Korea & 46.84 & 86.2 & 0.60 & 24.2 \\
\hline \multirow[t]{6}{*}{ Europe } & France & 59.30 & 75.6 & 0.60 & 26.9 \\
\hline & Germany & 82.28 & 87.5 & 0.60 & 43.2 \\
\hline & Poland & 38.67 & 65.6 & 0.35 & 8.9 \\
\hline & U.K. & 58.69 & 89.5 & 0.60 & 31.5 \\
\hline & Spain & 40.75 & 77.6 & 0.60 & 19.0 \\
\hline & Sweden & 8.86 & 83.3 & 0.60 & 4.4 \\
\hline North & Canada & 30.77 & 77.1 & 0.60 & 14.2 \\
\hline \multirow[t]{2}{*}{ America } & USA & 282.19 & 77.2 & 0.70 & 152.5 \\
\hline & Mexico & 98.93 & 74.4 & 0.40 & 29.4 \\
\hline South & Argentina & 39.20 & 76.0 & 0.40 & 11.9 \\
\hline \multirow[t]{3}{*}{ America } & Brazil & 179.00 & 67.0 & 0.37 & 44.4 \\
\hline & Peru & 27.60 & 61.0 & 0.36 & 6.1 \\
\hline & Chili & 16.08 & 71.0 & 0.40 & 4.5 \\
\hline
\end{tabular}

Note: UFW generation is on a wet mass basis for 2007. 
Table 2 Community composting centers for Mumbai, India

\begin{tabular}{ll}
\hline Description & Numbers and specification \\
\hline *Population/ $/ \mathrm{km}^{2}$ & 27000 \\
Food waste production/person/day & $0.25 \mathrm{~kg}$ \\
Number of composting center/km & 6 \\
Number of in-vessel composters/center & 2 \\
Specification of each composter & $6 \mathrm{~m}$ long and $2.4 \mathrm{~m}$ diameter \\
Composting cost (fixed and operational) & $85 \mathrm{US} \$ /$ ton wet compost \\
\hline
\end{tabular}

*Demographia (2007) 
Table 3 Estimated annual continental compost production from urban food waste (UFW) in Gkg

\begin{tabular}{lllll}
\hline Year & Asia & Americas & Europe & Africa \\
\hline 2005 & 83 & 38 & 29 & 15 \\
2010 & 94 & 41 & 30 & 18 \\
2015 & 103 & 45 & 34 & 21 \\
2020 & 114 & 48 & 33 & 23 \\
2025 & 125 & 52 & 34 & 26 \\
\hline
\end{tabular}

Note: compost generation is presented on a wet basis; these masses are computed from UFW production data presented in Table 1 assuming a 50\% mass reduction after inclusion of a bulking agent followed by composting. 
Table 4 Value of composted UFW for Asia and North America

\begin{tabular}{lcc}
\hline Valorization & \multicolumn{2}{c}{$\begin{array}{c}\text { Value of composted UFW } \\
\$ \text { US / ton }\end{array}$} \\
\cline { 2 - 3 } & Asia & $\begin{array}{c}\text { North } \\
\text { America }\end{array}$ \\
\cline { 2 - 3 } Fertilizer value $^{1}$ & $\$ 14.20$ & $\$ 24.75$ \\
Organic matter advantages $^{2}$ & $\$ 14.20$ & $\$ 24.75$ \\
Production from land saved $^{3}$ & $\$ 5.70$ & $\$ 2.85$ \\
Agricultural water $^{4}$ & $\$ 14.40$ & $\$ 14.40$ \\
Saved landfilling cost $^{5}$ & $\$ 35.70$ & $\$ 44.60$ \\
Greenhouse gas recovery $^{6}$ & $\$ 6.40$ & $\$ 6.40$ \\
Total savings & $\$ 90.20$ & $\$ 117.75$ \\
\hline Composting cost & $\$ 85.00$ & $\$ 110.00$ \\
\hline
\end{tabular}

Note:

${ }^{1} \$ 0.25, \$ 0.65$ and $\$ 0.65 / \mathrm{kg}$ for $\mathrm{N}, \mathrm{P}$ and $\mathrm{K}$ in Asia and $\$ 1.15, \$ 1.15$ and $\$ 0.60 / \mathrm{kg}$ in North America (Barrington, 2007) for compost at 50\% moisture containing 12, 1.2 and $16 \mathrm{~kg}$ of N, P and K per wet ton;

${ }^{2}$ less soil erosion and improve fertilizer adsorption efficiency for higher quality water resources; estimated at $100 \%$ of fertilizer value;

${ }^{3}$ land saved from landfilling after 20 years of recycling UFW for 2 and $1 \mathrm{crops} / \mathrm{yr}$ in Asia and North America, valued at $\$ 1000 /$ ha;

${ }^{4}$ improved water holding capacity estimated at $1.2 \mathrm{~m}^{3} / \mathrm{ton} / \mathrm{yr}$ for 4 years, after 6 rainfall events/year, at $\$ 0.5 \mathrm{US} / \mathrm{m}^{3}$ (Hamer, 2007);

${ }^{5}$ saving $50 \%$ of collection and transportation costs ( $\$ 16.00$ and $\$ 1.40$ US/ton UFW) plus $100 \%$ of landfill cost ( $\$ 18.60$ US/ton UFW) in North America, where 1.0 ton of compost represents 1.6 tons of UFW; in Asia, this cost is $20 \%$ lower; ${ }^{6}$ composting produces $50 \%$ less methane than landfilling; 1.6 tons of UFW generates an additional $56 \mathrm{~m}^{3}$ of methane when landfilled (West et al., 1998) at a cost of $\$ 4.00 \mathrm{US} /$ ton UFW. 
Table 5a Continental methane $\left(\mathrm{CH}_{4}\right)$ production from the anaerobic digestion of UFW in $\mathrm{Gkg} / \mathrm{yr}$

\begin{tabular}{lllll}
\hline Year & Asia & Americas & Europe & Africa \\
\hline 2005 & 17 & 8 & 6 & 3 \\
2010 & 19 & 8 & 6 & 4 \\
2015 & 21 & 9 & 7 & 4 \\
2020 & 23 & 10 & 7 & 5 \\
2025 & 25 & 11 & 7 & 5 \\
\hline
\end{tabular}

Source: Adhikari et al. (2006)

Note : UFW - urban food waste. 
Table $5 \mathrm{~b}$ Continental energy recovery potential from the anaerobic digestion of UFW in $10^{12} \mathrm{KJ} / \mathrm{yr}$

\begin{tabular}{lllll}
\hline Year & Asia & Americas & Europe & Africa \\
\hline 2005 & 952 & 448 & 336 & 168 \\
2010 & 1064 & 448 & 336 & 224 \\
2015 & 1176 & 504 & 392 & 224 \\
2020 & 1288 & 560 & 392 & 280 \\
2025 & 1400 & 616 & 392 & 280 \\
\hline
\end{tabular}

Note : UFW - urban food waste. 
Table 6 Total energy need versus that recovered from UFW anaerobic digestion

\begin{tabular}{|c|c|c|c|c|c|}
\hline \multirow[t]{2}{*}{ Continent } & \multirow[t]{2}{*}{ Country } & \multicolumn{2}{|c|}{ Energy consumption } & \multicolumn{2}{|c|}{ Energy from UFW } \\
\hline & & $\begin{array}{l}\mathrm{OE} \\
\mathrm{kg} / \mathrm{c}\end{array}$ & $\begin{array}{l}\text { Energy } \\
\mathrm{kW} / \mathrm{c} / \mathrm{d}\end{array}$ & $\begin{array}{l}\text { UFW } \\
\mathrm{kg} / \mathrm{c} / \mathrm{d}\end{array}$ & $\begin{array}{l}\text { Energy } \\
\text { of total }\end{array}$ \\
\hline \multirow[t]{6}{*}{ Africa } & Continent & 1628 & 2.74 & & \\
\hline & Algeria & 1038 & 1.74 & 0.34 & $0.35 \%$ \\
\hline & Ethiopia & 278 & 0.47 & 0.33 & $1.28 \%$ \\
\hline & Kenya & 481 & 0.81 & 0.37 & $0.84 \%$ \\
\hline & Morocco & 357 & 0.60 & 0.35 & $1.07 \%$ \\
\hline & Niger & 777 & 1.31 & 0.50 & $0.70 \%$ \\
\hline \multirow[t]{5}{*}{ Asia } & Continent & 991 & 1.67 & & \\
\hline & China & 1138 & 1.91 & 0.34 & $0.32 \%$ \\
\hline & India & 512 & 0.86 & 0.34 & $0.75 \%$ \\
\hline & Kuwait & 9076 & 15.25 & 0.60 & $0.07 \%$ \\
\hline & S. Korea & 4347 & 7.3 & 0.60 & $0.15 \%$ \\
\hline \multirow[t]{7}{*}{ Europe } & Continent & 3700 & 6.2 & & \\
\hline & France & 4518 & 7.6 & 0.60 & $0.14 \%$ \\
\hline & Germany & 4203 & 7.1 & 0.60 & $0.13 \%$ \\
\hline & Poland & 2370 & 4.00 & 0.35 & $0.16 \%$ \\
\hline & U.K. & 3918 & 6.59 & 0.60 & $0.16 \%$ \\
\hline & Spain & 3228 & 5.43 & 0.60 & $0.20 \%$ \\
\hline & Sweden & 5765 & 9.67 & 0.60 & $0.11 \%$ \\
\hline North & Continent & 7844 & 13.20 & & \\
\hline \multirow[t]{3}{*}{ America } & Canada & 8300 & 14.00 & 0.60 & $0.08 \%$ \\
\hline & USA & 7795 & 13.10 & 0.70 & $0.10 \%$ \\
\hline & Mexico & 1533 & 2.57 & 0.40 & $0.28 \%$ \\
\hline & Continent & 1083 & 1.82 & & \\
\hline \multirow[t]{4}{*}{ America } & Argentina & 1575 & 2.65 & 0.40 & $0.27 \%$ \\
\hline & Brazil & 1066 & 1.79 & 0.37 & $0.37 \%$ \\
\hline & Peru & 432 & 0.73 & 0.36 & $0.88 \%$ \\
\hline & Chili & 1652 & 2.78 & 0.40 & $0.26 \%$ \\
\hline
\end{tabular}

World $\quad 1674 \quad 2.81$

Earth Trends (2007); Adhikari et al. (2006).

Note : OE - oil equivalent; UFW - food waste; energy from food waste after anaerobic digestion and at $100 \%$ efficiency. All UFW production values are on a wet basis. 
Table 7 Example of urban anaerobic UFW digester for Mumbai, India

\begin{tabular}{ll}
\hline Description & Numbers and specification \\
\hline *Population $/ \mathrm{km}^{2}$ & 27000 \\
Food waste production/person/day & $0.25 \mathrm{~kg}$ \\
Number of anaerobic treatment center $/ \mathrm{km}^{2}$ & 1 \\
Water to be added $/ 0.25 \mathrm{~kg}$ of UFW & $0.15 \mathrm{~kg}$ \\
Capacity of digester $/ \mathrm{km}^{2}$ & $162 \mathrm{~m}^{3}$ \\
Dimension of digester & $10 \mathrm{~m}$ diameter and $4 \mathrm{~m}$ deep \\
& $@ 2 / 3$ capacity \\
Methane production /day & $290 \mathrm{~m}^{3}$ \\
Energy generation, $\mathrm{kW}$ & $130 \mathrm{~kW}(100 \%$ efficiency $)$
\end{tabular}

*Demographia (2007) 
Table 8 Value of anaerobically digested UFW for Asia and North America

\begin{tabular}{lcc}
\hline Valorization & \multicolumn{2}{c}{$\begin{array}{c}\text { Value from UFW } \\
\text { \$US / ton digested }\end{array}$} \\
\cline { 2 - 3 } & Asia & $\begin{array}{c}\text { North } \\
\text { America }\end{array}$ \\
\cline { 2 - 3 } Fertilizer value $^{1}$ & & $\$ 15.50$ \\
Organic matter advantages $^{2}$ & $\$ 8.90$ & $\$ 5.40$ \\
Production from land saved $^{3}$ & $\$ 3.10$ & $\$ 1.80$ \\
Agricultural water $^{4}$ & $\$ 3.60$ & $\$ 3.20$ \\
Energy production $^{5}$ & $\$ 28.80$ & $\$ 28.80$ \\
Saved landfilling operations $^{6}$ & $\$ 16.00$ & $\$ 20.00$ \\
Greenhouse gas recovery $^{7}$ & $\$ 4.00$ & $\$ 4.00$ \\
Total savings & $\$ 67.60$ & $\$ 78.70$ \\
\hline Anaerobic digestion cost & $\$ 43.20$ & $\$ 43.20$ \\
\hline
\end{tabular}

Note:

${ }^{1}$ same fertilizer value as compost because both process loose nutrients through leachate (compost) and from dewatering (anaerobic sludge);

${ }^{2} 70 \%$ loss of organic matter versus $15 \%$ loss with composting; estimated at $35 \%$ of fertilizer value;

${ }^{3}$ land saved from landfilling after 20 years of recycling UFW for 2 and 1 crops/yr In Asia and North America, valued at $\$ 1000 / \mathrm{ha}$;

${ }^{4}$ at $35 \%$ of the capacity of compost, because of organic matter losses during digestion;

${ }^{5} 1.0$ ton of wet UFW produces $360 \mathrm{~kW}$-h of energy at $80 \%$ efficiency when burned, worth $\$ 0.10 \mathrm{US} / \mathrm{kW}-\mathrm{h}$;

${ }^{6}$ saving of $0 \%$ collection, $75 \%$ transport and $100 \%$ landfilling;

${ }^{7}$ same recovery as for composting.

${ }^{8}$ the cost of producing this energy without gas scrubbing is evaluated at $\$ 0.15 \mathrm{US} / \mathrm{kW}-\mathrm{h}$ as experienced in Europe. 


\section{List of Figures:}

Figure 1 Continental urban solid waste production on an annual basis: (a) municipal solid waste (MSW); and urban food waste (UFW) (Source: Adhikari et al., 2006)

Figure 2 Estimated land requirements for landfilling of urban food waste (UFW)

Figure 3 Estimated continental cost requirement for handling of municipal solid waste (MSW) and urban food waste (UFW)

Figure 4 Estimated municipal solid waste (WSW) management cost reduction if urban food waste (UFW) is separated at source and treated onsite 


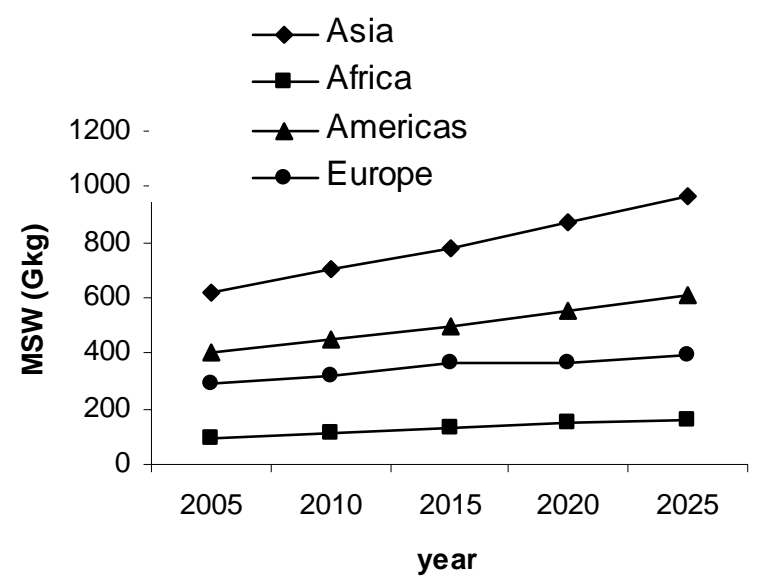

(a)

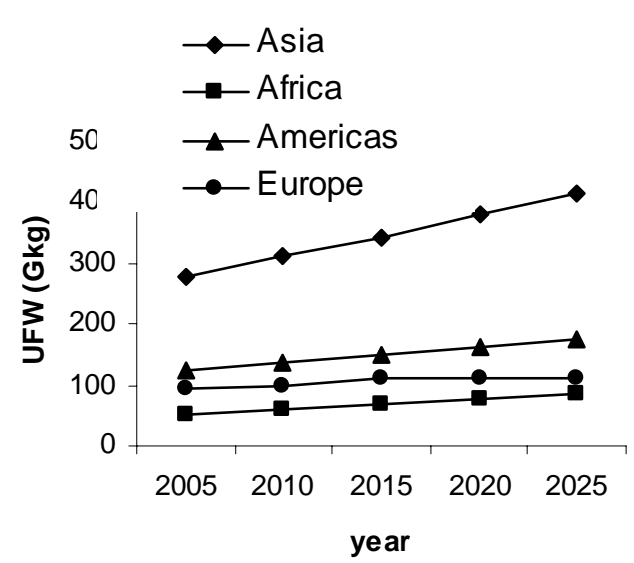

(b)

Figure 1 Continental urban solid waste production on an annual basis: (a) municipal solid waste (MSW); and (b) urban food waste (UFW)

(Source: Adhikari et al., 2006) 


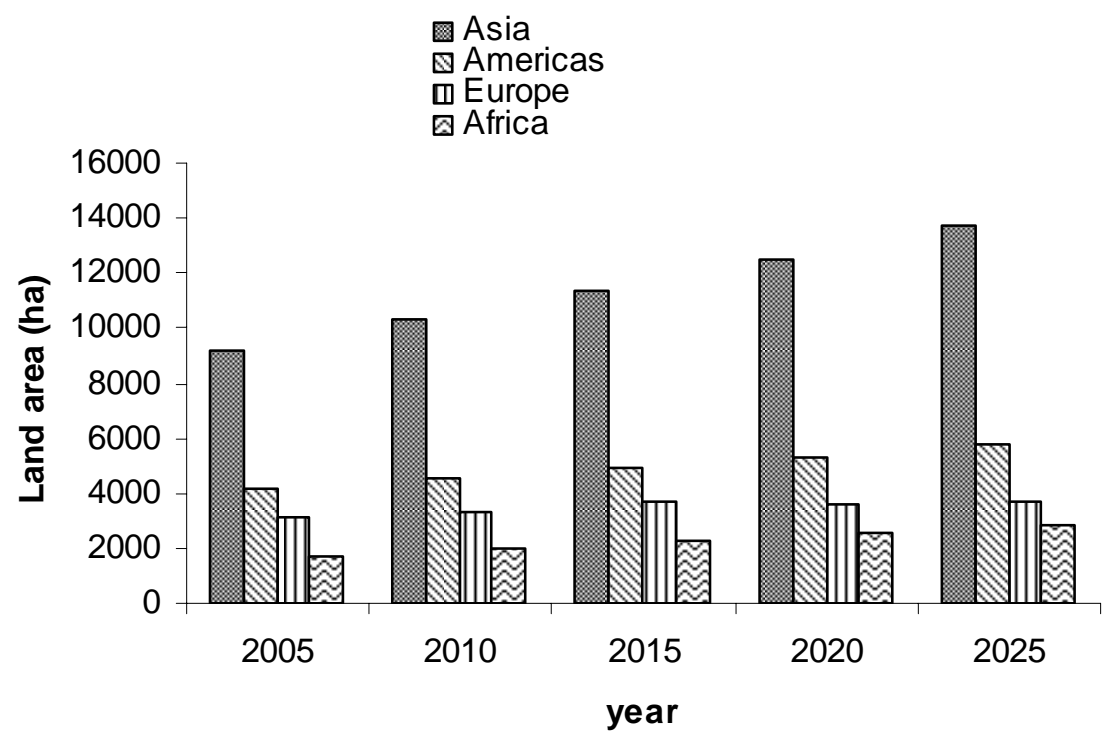

Figure 2 Estimated land requirement for landfilling of urban food waste (UFW) 


$$
\begin{array}{ll}
\rightarrow-\text { Asia (MSW) } & \rightarrow \text { Asia (UFW) } \\
\rightarrow-\text { Africa (MSW) } & \rightarrow \text { Africa (UFW) } \\
- \text { - Americas (MSW) } & \text { - Americas (UFW) } \\
-+- \text { Europe (MSW) } & - \text { Europe (UFW) }
\end{array}
$$

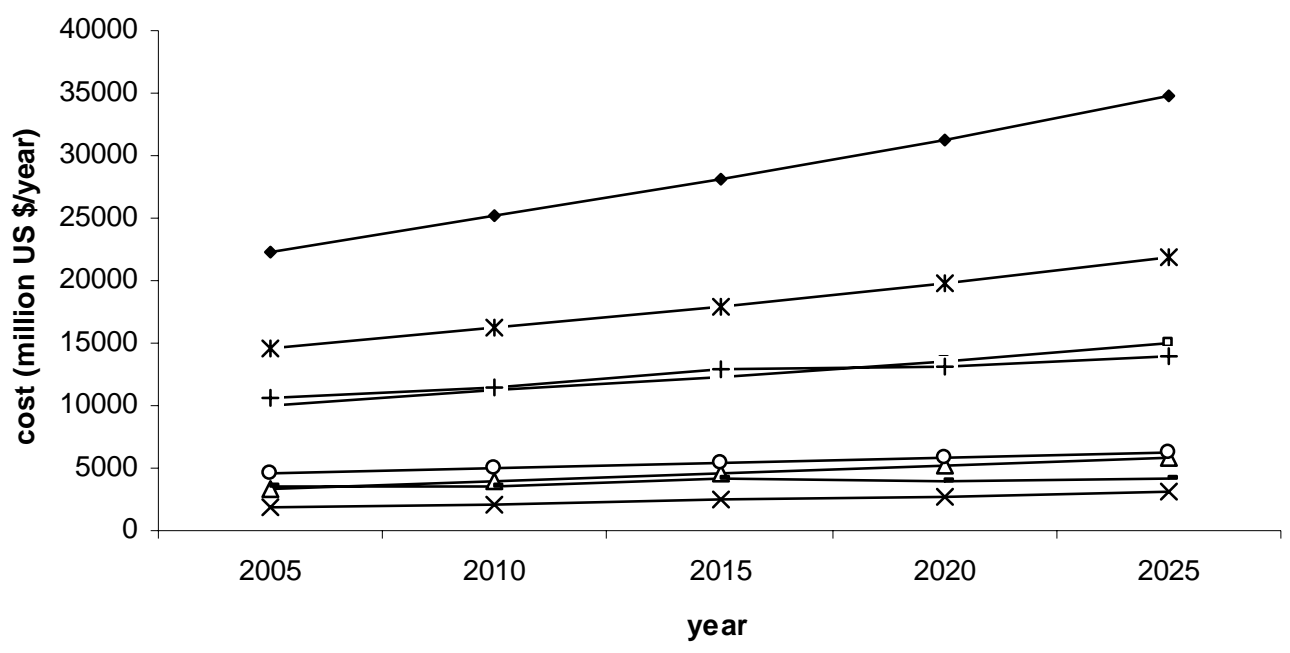

Figure 3 Estimated continental cost requirement for handling of municipal solid waste (MSW) and urban food waste (UFW) 


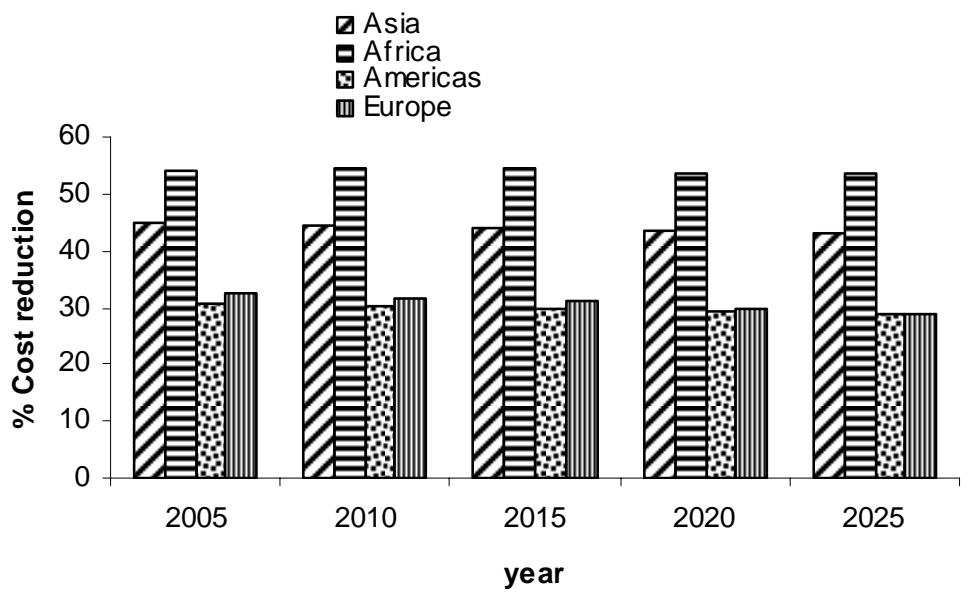

Figure 4 Estimated municipal solid waste (MSW) management cost reduction if urban food waste (UFW) is separated at source and treated onsite 